\title{
KADERISASI MUHAMMADIYAH DALAM ASPEK SOSIAL DI AMBARAWA PRINGSEWU LAMPUNG
}

\author{
Nihayati, Faza miftakhul farid \\ STKIP Muhammadiyah Pringsewu Lampung \\ E-Mail: nihayati@stkipmpringsewu-lpg.ac.id, fazafarid20@gmail.com
}

\begin{abstract}
An organization that want to exist needs qualified human resouces because it can strengthen the organiztion and become a leadership connector. Muhammadiyah is an organization that needs qualified human resources called militant cadre. Muhammadiyh generation is necessary because without it, Muhammadiyah will become weak organization. The problem happened is the difficulty in generating militant cadre in Muhammadiyah. From the beginning, Muhammadiyah has Al Maun spirit and become one of the imlementations that Muhammadiyah is social movement. Based on the problem mentioned, it is necessary to disclose the extent to which Muhammadiyah genertion in social aspect. Then, this study used descriptive qualitative method and the data gained from branch leader and assembly chairman of LazisMu, Dikdasmen, and Tabligh. The result of this study is appropriate with social theory such social act, cooperation between assembly in social activities and be able to find social consensus / social agreement that generates militan and less mlitant Muhammadiyah cadre.
\end{abstract}

Keywords: Muhammadiyah; generation; social.

Abstrak: Sebuah organisasi yang ingin terus eksis perlu memiki Sumber Daya Manusia berkualitas, karena SDM yang berkualitas akan memperkuat organisasi dan siap menjadi penyambung estafet kepemimpinan. Muhammadiyah merupakan sebuah organisasi yang memerlukan SDM berkualitas, ini disebut sebagai kader militan. Kaderisasi Muhammadiyah sebuah keniscayaan yang perlu dilakukan oleh Muhammadiyah, tanpa kaderisasi Muhammadiyah akan menjadi organisasi yang keropos. Permasalahan yang terjadi adalah sulitnya melahirkan kader-kader militan di Muhammadiyah. Muhammadiyah sejak awal berdirinya telah memiliki spirit al-Ma'un dan ini menjadi salah satu implementasi bahwa Muhammadiyah adalah gerakan sosial. Dari permasalahan tersebut, perlu diungkapkan sejauh mana kaderisasi Muhammadiyah dalam aspek sosial. Selanjutnya, dalam penelitian ini menggunakan metode deskriptif kualitatif dengan mengambil data dari Pimpinan Cabang dan Ketua Majelis LazisMu, Dikdasmen, dan Tabligh. Hasil dari penelitian ini sesuai dengan teori sosial yaitu tindakan sosial, bekersamanya antar Majelis dalam melakukan kegiatan sosial mampu menghasilkan konsensus sosial/kesepakatan sosial yaitu melahirkan kader muhammadiyah yang militan dan kurang militan.

Kata kunci: Kaderisasi; Muhammadiyah; sosial

\section{PENDAHULUAN}

Sebuah organisasi jika ingin terus bisa berkembang maka syarat utamanya adalah memiliki cukup sumber daya yang profesional sehingga bisa mendukung segala macam visi, misi ataupun tujuan dari organisasi.(Nasution, 2018). Organisasi hidup dalam waktu yang tidak dapat dipastikan, tetapi yang jelas organisasi harus bertahan dan 
berkelanjutan. Organisasi membutuhkan SDM yang berkualitas, baik pemimpin maupun pengikutnya.(Redatin, 2006)

Persyarikatan Muhammadiyah merupakan salah satu organisasi kemasyarakatan di Indonesia yang memiliki pimpinan di tingkat terrendah yaitu tingkat ranting, tingkat cabang. Pada tingkat Ranting dan Cabang memiliki anggota yang tidak banyak secara kuantitas. Hal itu terlihat dari kepemilikanAmalUsahaMuhammadiyah yang dimiliki oleh Pimpinan Ranting dan Cabang. Selain itu, dilihat dari keaktifan anggota Muhammadiyah untuk menggerakkan kegiatan-kegiatan persyarikatan Muhammadiyah. Pimpinan tingkat Ranting merupakan akar rumput, maka kalau tingkat Ranting dan Cabang tidak memiliki kader maka persyarikatan Muhammadiyah yang besar itu akan keropos.

Dalam Anggaran Rumah Tangga Muhammadiyah pada pasal 6 disebutkan bahwa (1) Cabang adalah kesatuan Ranting di suatu tempat yang terdiri atas sekurang-kurangnya tiga Ranting yang berfungsi: a. Melakukan pembinaan, pemberdayaan, dan koordinasi Ranting b. Penyelenggaraan pengelolaan Muhammadiyah c. Penyelenggaraan amal usaha (2) Syarat pendirian Cabang sekurang-kurangnya mempunyai: a. Pengajian / kursus berkala untuk anggota Pimpinan Cabang dan Unsur Pembantu Pimpinannya, Pimpinan Ranting, serta Pimpinan Organisasi Otonom tingkat Cabang, sekurang-kurangnya sekali dalam sebulan b. Pengajian / kursus muballigh / muballighat dalam lingkungan Cabangnya, sekurangkurangnya sekali dalam sebulan c. Korps muballigh / muballighat Cabang, sekurangkurangnya 10 orang d. Taman pendidikan Al-Quran / Madrasah Diniyah / Sekolah Dasar e. Kegiatan dalam bidang sosial, ekonomi, dan kesehatan f. Kantor (3) Pengesahan pendirian Cabang dan ketentuan luas lingkungannya ditetapkan oleh Pimpinan Wilayah atas usul Ranting setelah memperhatikan pertimbangan Pimpinan Daerah.

Menurut ketua LPCR PP Muhammadiyah Periode 2010-2015, Ahmad Norma Permata menyebutkan bahwa sebenarnya Cabang dan Ranting justru memainkan perang ujung tombak dalam kinerja persyarikatan Muhammadiyah: Pertama, Cabang dan Ranting merupakan ujung tombak dalam rekrutmen anggota dan kaderisasi. Kedua, ujung tombak dalam menjalankan dakwah keagamaan. Ketiga, ujung tombak dalam ukhuwah dengan organisasi Islam yang lain, maupun dalam perjumpaan dengan organisasi sosial yang lain. Keempat, duta persyarikatan di masyarakat. Kelima, ujung tombak dalam membela kepentingan ummat. (Permata, 2015, hal. 1)

Berdasarkan penjelasan di atas, kader yang lahir dari tingkat ranting dan cabang merupakan kader yang sangat diharapkan oleh persyarikatan. Hal ini menjadi sebuah tantangan yang besar untuk para pimpinan persyarikatan, dari tingkat pusat sampai dengan tingkat ranting. Bagaimana upaya yang dilakukan oleh para pimpinan tersebut untuk "membentuk" dan "menjaga" kuantitas dan kuaitas kader pada setiap lini.

Muhammadiyah sejak awal didirikannya oleh KH. Ahmad Dahlan pada tahun 1912H merupakan organisasi yang bergerak dibidang sosial. Muhammadiyah dengan spirit AlMa'unnya melahirkan lembaga-lembaga sosial yang banyak berkontribusi positif pada kehidupan masyarakat. Misalnya adanya Amal Usaha dibidang pendidikan, bidang kesehatan, bidang ekonomi. Muhammadiyah Cabang Ambarawa merupakan salah satu cabangyang memiliki lembaga-lembaga sosial yang lengkap, seperti Amal Usaha di bidang Pendidikan dimulai dari TPA 
(Tempat Penitipan Anak), PAUD, TK, SD, SMP, SMK,Panti Asuhan Putri Aisyiyah, BTM (Baitut Tamwil Muhammadiyah). Kegiatan sosial pada masyarakat di tingkat Cabang memberikan dampak atau tidak terhadap kaderisasi perlu dikaji mengingat semakin minimnya kader yang berada di lini bawah persyarikatan Muhammadiyah ini.Kembali melihat tantangan Muhammadiyah dalam uraian sebelumnya, kebutuhan akan kader di banyak lini dakwah dan dengan kualitas yang handal adalah sebuah keniscayaan, karena itu transformasi kader harus berjalan secara masif di setiap lini dakwah Muhammadiyah.

\section{METODE PENELITIAN}

Penelitian ini merupakan penelitian deskriptif kualitatif dengan informan dari pimpinan cabang Muhammadiyah (ketua dan sekretaris) dan ketua Majelis LazisMu, Majelis Dikdasemen dan Majelis Tabligh. Teknik pengumpulan data primer dengan cara melakukan wawancara dengan para informan tersebut. Data sekunder diambil dari media online, media cetak, dan dokumentasi-dokumentasi yang mendukung penelitian ini.

Beberapa tentang referensi dapat ditemui di antaranya: beberapa peran kaderisasi (Rahmawati, 2016) diantaranya yaitu: Pertama, pewarisan nilai-nilai organisasi yang baik. Pada proses kaderisasi terdapat transfer nilai dan prinsip organisasi. Kedua, Penjamin keberlangsungan organisasi. Ketiga, sarana belajar bagi kader baru. Kaderisasimerupakan fasilitas mempelajari hal-hal baru yang belum diketahui.

J. Susanto (2016) Istilah kader atau kaderisasi (proses pengkaderan) bukan sekedar predikat formal yang dimiliki oleh seseorang karena mengikuti pendidikan dan latihan tertentu, dan karena berbagai serifikat formal yang dimiliki. Istilah kader lebih mengacu pada dimensi substansial berupa kualitas perjuangan yang dimiliki seseorang. Kaderisasi dipandang sebagai upaya yang sistematik, terus menerus dan berkelanjutan secara konsisten untuk menumbuhkan, mengembangkan dan membentuk insan-insan pejuang bangsa dengan kualitas dan karakteristik tertentu.

Kaderisasi dalam tubuh Muhammadiyah menghasilkan kader militan, dimana kader tersebut merupakan embrio yang perlu dipersiapkan untuk menjadi pemimpin sebagai pemegang estafet kepemimpinan mendatang. Kader yang dipersiapkan menjadi pemimpin yang akan datang perlu di persiapkan secara matang, karena menjadi pemimpin yang baik perlu dilakukan proses penempaan.

Muhammadiyah akansemakin eksis di bumi Indonesia danmampu memberikan kontribusipositif kepada umat dan bangsa ini,kalau dengan serius mempersiapkan kader-kader secara baik(Shobron, 2010). Dalam berbagai kesempatan, akhir-akhir ini sering dilansir bahwa perkembangan Muhammadiyah yang amat pesat di bidang organisasi tidak dapat diimbangi oleh jumlah dan mutu kader yang dihasilkannya. Penanganan amal usaha yang menuntut keahlian profesional dan pragmatisme gerakan sering menggiring Muhammadiyah untuk menengok kepada "tenaga profesional" dan mengesampingkan kader-kader yang dihasilkan oleh sistemnya sendiri. (Rukman, 2012)

Program bidang pengkaderan hasil muktamar ke-46 (2010) menegaskan visi pengembangannyab sebagai berikut, "Berkembangnya kualitas anggota dan kader Muhammadiyah sebagai pelaku gerakan yang memiliki keunggulan kapasitas, komitmen ideologis, dan mampu memajukan serta menyebar luaskan peran Muhammadiyah dalam dinamika kehidupan umat, bangsa dan perkembangan global."(Tanfidz 
Keputusan Muktamar Muhammadiyah ke-46,2010:124).

Dalam Sistem Perkaderan MuhammadiyahMPKPPMuhammadiyah (2016: 34) tertulis Pedoman Majelis Pendidikan Kader (2010) Pasal Ayat 4 ditegaskan bahwa, "Kader adalah anggota inti yang terlatih serta memiliki komitmen terhadap perjuangan dan citacita Persyarikatan". Jadi, jelas bahwa orang-orang yang berkualitas itulah yang tepilih dan berpengalaman dalam berorganisasi, taat asas dan berinisiatif, yang dapat disebut sebagai kader.Jenisjenis kegiatan kaderisasi yang dapat dilaksanakan secara umum terdiri dari dua kategori yang termaktub pada buku SPM (2016: 57-63), yaitu :

1. Pengkaderan Utama, yaitu kegiatan kaderisasi pokok yang dilaksanakan dalam bentuk pendidikan atau pelatihan untuk menyatukan visi dan pemahaman nilai ideologis serta system dan aksi gerakan yang diselenggarakan oleh Pimpinan Persyarikatan atau Majelis Pendidikan Kader (Pusat sampai Cabang) dan Amal Usaha Muhammadiyah . Kaderisasi yang termasuk kategori perkaderan utama adalah Darul Arqam dan Baitul Arqam.

2. Pengkaderan Fungsional, yaitu kegiatankaderisasiyang dilaksanakan dalam bentuk pendiidkan, pelatihan, kursus atau kajian intensif yang terstruktur namun tidak di tetapkan standar kurikulumnya secara baku untuk mencukupi kebutuhan dan fungsi tertentu dari majelis atau lembaga. Pengkaderan fungsional dilaksanakan sebagai pendukung pengkaderan utama dan guna pengembangan sumber daya kader.

\section{KERANGKA TEORI}

Nursid Suatmaja (2006: 2.19) mengungkapkan bahwa ilmu sosial yang secara khusus mempelajari "interaksi sosial " ini adalah sosiologi. Max Weber dalam I.B. Wirawan (2012: 104) mendefinisikan sosiologi sebagai suatu ilmu pengetahuan yang berusaha memperoleh pemahaman interpretatif mengenai arah dan akibat-akibat dari suatu tindakan. Batasan sederhana sosiologi adalah ilmu pengetahuan tentang masyarakat. Calhoun dalam Fredian Tonny Nasdian (2015: 31-32) mengungkapkan terdapat lima konsep dasar sosiologi yang lazim digunakan dalam menganalisis masyarakat, yaitu:

1. Struktur sosial: Pola-pola hubungan sosial, posisi sosial, dan jumlah penduduk menurut kategori sosial tertentu.

2. Tindakan sosial. Cara bagaimana individu dan grup sosialnya menjadi seperti yang diinginkannya, membuat kesaling-ketergantungan.

3. Integrasi fungsional. Kesalingtergantungan diantara unsur-unsur dari suatu sistem sosial.

4. Kekuasaan. Kemampuan suatu aktor sosial (individu, grup, organisasi) mengerahkan pihak lain untuk melaksanakan keinginannya atau menjamin perolehan manfaat dari tindakan pihak lain.

5. Kebudayaan. Bahasa, norma-norma, nilai-nilai, kepercayaan-kepercayaan, pengetahuan dan simbol-simbol yang membangun suatu "cara hidup".

Interaksi sosial sebagai konsep dasar sosiologi, interaksi ini bagaimanapun intensitasnya, selalu dialami oleh tiap individu dan selalu terjadi di masyarakat. Manusia sebagai anggota masyarakat, dilandasi oleh berbagai kebutuhan, selalu melakukan interaksi, baik interaksi edukatif, interaksi ekonomi maupun interaksi budaya dan interaksi politik. Semua interaksi tersebut termasuk interaksi sosial. Hasil interaksi sosial berbagai pihak biasanya menelorkan konsensus sosial. Konsensus sosial atau 
kesepakatan sosial ini juga termasuk konsep dasar sosiologi.

Menurut Gillin dan Gillin dalam Fredian Tonny (2015: 45-55), ada dua macam proses sosial yang timbul sebagai akibat adanya interaksi sosial, sehingga keduanya sekaligus menunjuk pada bentuk-bentuk interaksi sosial, yaitu:

1. Proses sosial yang mendekatkan atau mempersatukan (asosiatif), meliputi:

a. Kerjasama (Cooperation); bekerja bersama dalam rangka mencapai sesuatu tujuan bersama. Faktorfaktor yang mendorong terjadinya kerjasama meliputi motivasi atau kepentingan pribadi (tolong menolong; bekerjasama untuk mewujudkan kepentingan pribadi), kepentingan umum (kerjabakti untuk kepentingan bersama), motivasi altruistik (semangat pengabdian panggilan tanpa pamrih untuk menolong sesama -), tuntutan situasi (bekerjasama untuk mengatasi situasi)

b. Akomodasi (Accommodation); usahausaha untuk meredakan suatu pertentangan, untuk mencapai kestabilan hubungan antar-grup. Bentuk-bentuk akomodasi antara lain paksaan, kompromi, mediasi, konsililasi dan toleransi.

c. Asimilasi (Assimilation); proses sosial yang ditandai dengan usaha-usaha mengurangi perbedaan yang terdapat antara orang perorangan atau kelompokkelompok manusia.

2. Proses sosial yang menjauhkan atau mempertentangkan (disosiatif)

a. Persaingan (Competition); suatu proses sosial dimana dua orang atau lebih berjuang dengan bersaing satu sama lain untuk memiliki atau mempergunakan varang-barang yang berbentuk material atau non material. b. Konflik (Confict); proses sosial dimana orang-perorangan atau kelompok manusia berusaha memenuhi tujuannya dengan jalan menantang pihak lain atau lawan dengan ancaman dan atau kekerasan.

Interaksi sosial antara seseorang dengan yang lainnya terjadi dalam kelompok. Kelompok tersebutatau lebih tepat kelompok sosial tempat terjadinya interaksi antarindividu, merupakan kumpulan manusia terdiri atas dua orang atau lebih, telah saling mengenal dalam waktu yang relatif lama, ada kaitan rasa senasib, diikat oleh nilai dan norma yang sama, serta memiliki rasa persatuan. Kelompok sosial ini, merupakan konsep dasar yang penting dalam studi sosiologi. Secara formal, masyarakat manusia itu terikat dalam wadah kelompok sosial ini.

Selama manusia hidup dan mempunyai vitalitas dan dinamika, proses sosial ini tidak akan berhenti. Masyarakat, cepat ataupun lambat, selalu beranjak dari tingkat terbelakang ke tingkat berkembang sampai menjadi masyarakat modern. Sebagai akibat terjadinya proses sosial ini, terjadi pula perubahan sosial yaitu perubahan yang dialami berbagai aspek kehidupan dan didukung serta dialami oleh sebagaian besar anggota masyarakatyang bersangkutan. Proses sosial dan perubahan sosial, merupakan konsep dari sosiologi yang dapat dialami serta dihayati oleh kita si masyarakat dari waktu ke waktu. Apabila proses sosial dan perubahan sosial itu mengarah kepada kemajuan, masyarakat tersebut mengalami proses modernisasi.

\section{Muhammadiyah Sebagai Gerakan Sosial}

Muhammadiyah merupakan salah satu gerakan yang menitikberatkan pada bidang sosial. Sejak awal berdirinya Muhammadiyah melandasan surat AlMa'un, berkali-kali KH. Ahmad Dahlan 
mengajarkan al-Ma'un kepada para santrinya dan mengajak para santrinya untuk menerapkan al-Ma'un dalam kehidupan sehari-hari, yaitu dengan mendatangiorang-orang miskin dan anakanak yatim dengan memberikan makan, pakaian dan memberikan pendidikan. Hal tersebut terimplementasi hingga saat ini, pendirian sekolah, rumah sakit, panti asuhan, juga pembentukan Majelis Pemberdayaan Masyarakat MPM) pada Muktamar 2005 di Malang merupakan bukti konkret bahwa Muhammadiyah konsen pada bidang sosial. Tim Penulis Majelis Diktilitbang PP Muhammadiyah (2016: 164) menyebutkan bahwa dalam pandangan Muhammadiyah, iman bukanlah barang pasif melainkan aktif. Iman buka sesuatu yang absolut dan tidak dapat diamati, tidak dapat diukur, melainkan iman dapat diamati, diukur dan terlihat dalam interaksi sosial.

$$
\text { Musthafa Kamal }
$$

(2009:138)

menyebutkan bahwa sifat Tajdid yang dikenakan pada gerakan Muhammadiyah disamping berupaya memurnikan ajaran Islam dari berbagai kotoran yang menempel pada tubuhnya, juga termasuk upaya Muhammadiyah melakukan berbagai pembaharuan caracara pelaksanaan ajaran Islam dalam kehidupan bermasyarakat, seperti penyantunan terhadap fakir miskin dan anak yatim.

Atas dasar spirit Al-Ma'un, KH. Ahmad Dahlan memberi isyarat bahwa Islam dalah agama yang menekankan bukanhanyaaspekritualdanmengabaikan aspek sosial. Akan tetapi, seorang muslim dikatakan shalih dalam menjalankan ibadah ritual, apabila melahirkan akhlaqul karimah dan kepekaan sosial terhadap lingkungan sekitarnya. Bahkan, orang yang melupakan dan tidak peduli ada nasib anak yatim dan orang-orang miskin digolongkan sebagai pendusta agama. (Tim Penulis Majelis Diktilitbang: 2016, hal: 164)

\section{HASIL DAN PEMBAHASAN}

Penyajian data (Display Data) dilakukan dengan uraian singkat, bagan, hubungan antara kategori, dan sejenisnya. Hal ini dimaksudkan untuk memudahkan peneliti dalam memahami apa yang terjadi, kemudian menggambarkan secara naratif.

\section{Kaerisasi di Pimpinan Cabang Muhammadiyah Ambarawa}

Menurut bapak Sukisno RH selaku ketua PCM Ambarawa menyatakan bahwa kaderisasi yang terjadi di Cabang Ambarawa jika dikaitkan dengan aspek sosial sudah berjalan, tetapi tidak maksimal. Kegiatan sosial yang dilakukan oleh Majelis LazisMu misalnya, dalam hal memberikan santunan kepada kaum dhu'afa dan fakir miskin sejauh pengamatan bpk Sukisno, tidak terlalu besar dampak kaderisasi terhadap kegiatan sosial tersebut. Hanya pengingkatan yang sangat kecil, sekedar menjadi simpatisan muhammadiyah, tidak sampai pada kader militan. Selaku ketua PCM selalu mengarahkan kepada jajaran pimpinan dan majelis-majelis dibawah naungan PCM untuk membina kader-kader Muhammadiyah yang sudah ada, meningkatkan "kualitas kader" melalui pelibatan aktif pada kegiatan-kegiatan sosial yang dilakukan oleh PCM atau mejelis-majelis tertentu, dengan tujuan agar eksistensi mereka diakui. Karena pada dasarnya kader di lingkungan cabang Ambarawa secara kuantitas banyak, akan tetapi secara kualitas atau yang disebut kader militan tidak banyak. Padahal kader-kader militan itulah yang kelak akan menjadi estafet kepemimpinan. Pernikahan juga berpengaruh pada kaderisasi dalam aspek sosial dicabang Ambarawa. Beberapa kader muhammadiyah yang menikah dengan non-kader pada akhirnya tidak lagi aktif di persyarikatan. 
Masih menurut ketua PCM, PCM Ambarawa sudah berupaya untuk memaksimalkan kaderisasi dalam aspek sosial, yaitu melalui pembinaan jamaah, pengajian rutin bulanan, kajian setiap malam jum'at, kajian ba'da subuh setiap hari ahad. Juga pemberian beasiswa kepada para siswa yang bersekolah di AUM, yang diharapkan mereka kelak mampu menjadi kader muhammadiyah.

Lebih lajut sekretaris PCM, bapak Imam Baihaqi mengungkapkan bahwa PCM juga memberikan surat rekomendasi kepada kader untuk melanjutkan studi dengan kuliah di PTM-PTM tertentu dan bahkan pernah memberikan beasiswa kepada kader kita ketika kuliah. Bantuan tersebut diharapkan dapat mengikat kader-kader tersebut setelah selesai studi akan kembali mengabdi kepada Muhammadiyah di Ambarawa.

Kaderisasi juga dilakukan di tingkat AUM (sekolah). Pengadaan Baitul Arqam untuk tenaga pendidik dan kependidikan di lingkungan AUM sudah dilakukan oleh PCM melalui Majelis Dikdasmen yang bekerjasama dengan majelis Tabligh. Kelemahan Baitul Arqam yang diadakan oleh Cabang yang bekerja sama dengan AMM tidak berjenjang, jadi terkesan hanya formalitas, bersifat pengulangan dan tidak bersifat up grading.Pelibatan pada agenda-agenda cabang misalnya menjadi bagian dari panitia Tabligh Akbar Jelang Ramadhan, panitia pengumpulan zakat. Serta pendelegasian para calon kader pada kegiatan-kegiatan yang diagendakan oleh PDM atau PWM. Misalnya pelatihan muballigh/muballighat.

\section{Kaderisasi di Ketua Majelis}

Penggalian data selanjutnya dilakukan kepada ketua Majelis Tabligh, Majelis Dikdasmen dan Majelis LazisMu. Penggalian data kepada ketua-ketua Majelis ini bertujuan untuk mendapatkan informasi secara langsung terkait dengan kaderisasi muhammadiyah dalam aspek sosial, dimana majelis-majelis tersebut merupakan pelaksana kegiatan sosial di cabang Ambarawa dan bersinggungan langsung dengan jama'ah, baik simpatisan maupun non simpatisan.

Penggalian data pada majelis LazisMu dengan program kerja tentang penerimaan zakat mal, zakat pertanian, dan zakat profesi dibagikan kepada 8 asnaf dari kalangan keluarga Muhammadiyah, akan tetapi jika terdapat lebih, maka diberikan kepada keluarga di luar muhammadiyah. Pembagian zakat tersebut mampu menambah jumlah simpatisan, belum pada level kader. Simpatisan tersebut mulai mau mengikuti kegiatan pengajianpengajian yang diadakan oleh Majelis Tabligh di cabang Ambarawa. Pengajian yang dilakukan oleh Majelis Tabligh sudah intens dan aktif, ini menjadi salah satu bekal untuk para pemuda untuk menjadi mubaligh cabang yang siap di tugaskan di rantting-ranting juga di cabang. Zakat yang diberikan masih bersifat konsumtif, bukan produktif. Selain pada pembagian zakat, LazisMu juga memberikan santunan kepada keluarga yang terkena musibah, misalnya membantu pengobatan anggota keluarga yang sakit dan tergolong membutuhkan bantuan biaya besar. Selain itu, LazisMu juga membantu korban bencana bekerjasama dengan MDMC (Muhammadiyah Disarter Management Center) PWM Lampung. Serta bantuan kemanusiaan tingkat lokal, nasional maupun internasional. Pemberian zakat, infaq dan shodaqoh yang diberikan LazisMu kepada warga sekitar ada dampak pada tingginya minat keluarga-keluarga yang dibantu tersebut untuk menyekolahkan anak-anak mereka di AUM.

Melalui wawancara dengan ketua majelis tabligh, majelis dikdasmen dan majelis LazisMu menyatakan bahwa kaderisasi muhammadiyah melalui kegiatan-kegiatan sosial yang dilakukan tidak memiliki target khusus akan 
menjadikan kader secara tertulis pada setiap sasaran kegiatan sosial. Hal ini diperkuat dengan pernyataan Ketua Majelis LazisMu bahwa tidak adanya Mou secara tertulis kepada para siswa yang mendapat bantuan beasiswa. Akan tetapi ada pendampingan yang intens terhadap siswa yang mendapatkan beasiswa dilakukan oleh Majelis Dikdasmen, yaitu dengan kaderisasi di sekolah dengan dorongan untuk aktif di Tapak Suci dan IPM untuk tingkat SMP dan SMK, dan ini dinilai efektif.

Kaderisasi dalam aspek sosial ini juga dilakukan tidak hanya kepada siswa, juga kepada tenaga pendidikdankependidikan di Amal Usaha Muhammadiyah yang ada di Cabang Ambarawa. Majelis Dikdasmen bekerjasama dengan majelis Tabligh mengadakan kajian rutin bulanan yang wajib diikuti oleh tenaga pendidik dan kependidikan dari tingkat PAUD sampai SMK. Kajian tersebut menekankan pada kajiankeislamandankemuhammadiyahan sekaligus mengarahkan kepada peserta pengajian untuk aktif menjadi kader di persyarikatan cabang Ambarawa sesuai dengan ortom yang ada, seperti Pemuda Muhammadiyah, Nasyiatul Aisyiyah, Asiyiyah atau Muhammadiyah itu sendiri.Karena pada realitanya, tenaga pendidik dan kependidikan yang ada di lingkungan AUM Ambarawa tidak $100 \%$ orang Muhammadiyah. Dengan pengajian bulanan di diharapkan ada peningkatan dari tidak tahu menjadi tahu kemudian menjadi simpatisan dan selanjutnya menjadi kader yang bersedia aktif di ortom. Idealnya tenaga pendidik dan kependidikan di AUM itulah yang akan mengkader para siswa di sekolah. Tetapi pada kenyataannya, harapan PCM dari kegiatan ini belum maksimal, kesediaan untuk aktif pada ortom yang ada belum berjalan sesuai harapan, menurut majelis Dikdasmen karena belum adanya pernyataan "wajib aktif" di ortom pada tenaga yang ada di AUM.

\section{Kaderisasi Aspek Sosial}

Program kerjasama antar Majelis di PCM Ambarawa sesuai dengan konsep dasar sosiologi dalam menganalisis masyarakat diantaranya adalah tindakan sosial. Tindakan social merupakan salah satu bentuk dari interaksi sosial, dimana hasil interaksi sosial dengan berbagai pihak mampu menghasilkan konsensus social atau kesepakatan social. Tindakan sosial adalah sebuah upaya bagaimana antara satu dan lain individu atau grup sosial terdapat hubungan kesalingtergantungan. Dalam hal ini Majelis Tabligh bekerjasama dengan Majelis Dikdasmen dengan melahirkan kegiatan diantaranya adalah Baitul Arqam bagi pendidik dan tenaga kependidikan di AUM serta kajian rutin. Majelis LazisMu bersama Majelis Dikdasmen memunculkan program beasiswa bagi para siswa yang dipandang kurang mampu, Majelis LazisMu dan Tabligh melahirkan agenda Tabligh Akbar Jelang Ramadhan sekaligus pembagian zakat kepada para mustahiq. Juga pemberian santunan pada kajian-kajian rutin secara insidental.

Muhammadiyah sebagai organisasi yang bergerak dibidang sosial sudah diterapkan di PCM Ambarawa. Spirit Al-Ma'un yang terimplementasi dalam kegiatan-kegiatan sosial sebagai implementasi dari iman dan taqwa kepada Allah SWT, dan berdampak pada kaderisasi di tingkat cabang. Kaderisasi yang dilaksanakan di Pimpinan Cabang Muhammadiyah Ambarawa awalnya sesuai dengan pengkaderan yang dilakukan semasa K.H. Ahmad Dahlan, yaitu upaya beliau dalam membina kalangan muda untuk belajar mengembangkan misi gerakan Muhammadiyah ke dalam kehidupan masyarakat, khususnya umat Islam. Melalui program kerja yang dilakukan oleh Majelis LazisMu, Majelis Dikdasmen dan Majelis Tabligh pada PCM Ambarawa 
terutama bidang sosial memberikan dampak terjadinya kaderisasi, yang pada awalnya kader-kader tersebut tidak dididik secara sistem yang tertuang pada SPM (Sistem Pengkaderan Muhammadiyah). Cara yang dipakai oleh K.H. Ahmad Dahlan berupa pembinaan secara langsung dengan membimbing dan sekaligus melibatkan orang muda dalam berbagai aktivitas Muhammadiyah. Seperti yang dilakukan oleh Majelis LazisMu, penerimaan zakat dilakukan oleh Amil dibantu kalangan pemuda. Para pemuda inilah yang nantinya terhimpun dalam Angkatan Muda Muhammadiyah. Majelis Tabligh memiliki program kajian-kajian rutin yang disitu tujuannya adalah pembinaan secara langsung, yang kemudian disebarkan pada masjid atau musholla di ranting-ranting maupun cabang untuk memberikan materi kajian khususnya pada bulan Ramadhan, ini disebut Corps Muballigh Muda. Majelis Dikdasmen juga bekerjasama dengan Majelis Tabligh mengadakan kajian rutin tenaga pendidik dan kependidikan pada AUM ini merupakan pembinaan dan penguatan Al-Islam dan kemuhammadiyahannya untuk kemudian bisa menjadi kader, dimana mereka akan mengkader para siswa yang ada di sekolah tersebut.

Secara garis besar ada dua jenis kegiatan kaderisasi yang sudah dilaksanakan oleh PCM Ambarawa yaitu Perkaderan Utama berupa Baitul Arqam, dimana Baitul Arqam dalam SPM sasarannya mulai simpatisan, anggota, pimpinan Muhammadiyah, dan pimpinan (middle manager ke bawah) serta karyawan AUM. Di PCM Ambarawa, Baitul Arqam dilaksanakan sebatas karyawan AUM, untuk simpatisan, anggota belum dilaksanakan. Kedua Perkaderan Fungsional dalam bentuk kegiatannya yaitu pengajian khusus dengan tujuan peneguhan paham agama dan ideologi gerakan Muhammadiyah di lingkungan cabang. Juga diklat khusus dalam bentuk kegiatannya pelibatan kepanitiaan dalam agenda-agenda cabang, seperti yang disampaikan oleh sekretaris cabang Ambarawa.

Kaderisasi melalui agenda sosial terbukti efektif meningkatkan simpatisan, kemudian anggota, kemudian anggota diikutkan pada kegiatan Perkaderan Utama melalui Baitul Arqam, juga secara aktif mengikuti Perkaderan Fungsional misalnya kajian-kajian rutin yang dilakukan oleh Majelis Tabligh yang bekerja sama Majelis Dikdasmen dan Majelis LazisMu. Akan tetapi, terbatasnya Baitul Arqam yang dilakukan oleh PCM Ambarawa (hanya pada tenaga pendidik dan kependidikan pada AUM), menjadikan calon kader muda tidak mengikuti Perkaderan Utama yang tersistematis. Ketidakikut sertaan kader muda pada Perkaderan Utama kami melihat tidak berdampak pada militansinya sebagai kader. Perkaderan Fungsional di PCM Ambarawa dalam bentuk pelibatan kepanitiaan dalam agenda-agenda cabang, keikutsertaan pada kegiatan kajian rutin, pendelegasian kegiatan yang dilakukan oleh PDM. Perkaderan Fungsional tidak terstruktur, dengan ini terlihat militansi kader, lebih cenderung pada kaderisasi alami.

\section{PENUTUP}

Dari pembahasan dan sajian serta analisis data di atas, maka penelitian ini memiliki beberapa kesimpulan terkait dengan kaderisasi Muhammadiyah dalam aspek sosial di PCM Ambarawa Daerah Pringsewu. Kegiatan sosial yang dilakukan PCM Ambarawa melalui Majelis LazisMu, Majelis Dikdasmen dan Majelis Tabligh memberikan efektifitas dalam kaderisasi Muhammadiyah di cabang Ambarawa. Pembagian zakat, infaq, shodaqoh, beasiswa, kajian-kajian dan Baitul Arqam merupakan contohcontoh dari kegiatan sosial yang mampu 
menambah jumlah simpatisan secara kuantitas. Secara kualitas, yaitu dengan lahirnya kader. Kaderisasi tersebut membutuhkan proses, maksudnya calon kader tersebut berawal dari simpatisan, anggota, calon kader, dan kader. Kaderisasi dalam Muhammadiyah secara umum terdiri dari dua kategori, yaitu perkaderan utama dan perkaderan fungsional. Perkaderan utama salah satu kegiatannya adalah Baitul Arqam. Hal ini sudah sesuai dengan SPM yang di standarkan oleh Majelis Pendidikan Kader PP Muhammadiyah. Baitul Arqam dilaksanakan pada tingkat cabang yang diikuti oleh pendidik dan tenaga kependidikan AUM Muhammadiyah. OutputdariBaitulArqamyangdiharapkan oleh PCM adalah aktifnya pendidik dan tenaga kependidikan pada ortomortom di lingkungan cabang Ambarawa. Tetapi, pada kenyataannya harapan itu belum terjadi, bahkan ketika kemudian di sambung dengan perkaderan fungsional dengan diundang kajian-kajian yang dilakukan ortom pun tidak banyak yang bersedia hadir. Kajian-kajian yang diikuti adalah kajian yang diadakan Majelis Dikdasmen bekerjasama dengan Majelis Tabligh.

Perkaderan fungsional lebih efektif karena kaderisasi ini lebih bersifat alami, bukantuntutan, ataubahkanketerpaksaan. Akan tetapi lebih pada panggilan hati. Pembagian zakat, infaq dan shodaqoh pada fakir miskin, pemberian beasiswa, pelibatan kepanitiaan pada agendaagenda di Cabang, pengadaan kajiankajian rutin untuk masyarakat umum, serta pendelegasian kegiatan-kegiatan di Daerah, hal demikian merupakan kaderisasi yang tidak tersruktur. Sekalipun tidak terstruktur, akan tetapi lebih mengena, sehingga menjadikan para kader tersebut lebih militan.

Dengan semakin banyak kader yang militan, maka muhammadiyah ke depan akan lebih besar dan terus berkibar, sebagaimana ungkapan dalam pepatah-petitih khas Muhammadiyah: sebelum patah telah tumbuh, sebelum hilang telah berganti"; kader adalah anak panah Muhammadiyah, yang siap dilepaskan ke berbagai arah sasaran.

Setelah penelitian diambil kesimpulan ini, maka sangat tepat jika terdapat saran yang bersifat membangun terkait dengan kaderisasi Muhammadiyah dalam aspek sosial di tingkat cabang ini. Adapun saran yang bisa peneliti sampaikan adalah sebagai berikut:

1. Perlu kaderisasi yang matang untuk tenaga pendidik dan kependidikan di AUM dengan cara "mewajibkan" mereka untuk aktif di persyarikatan atau ortom-ortom yang sesuai karena mereka yang akan mengkader para siswa di sekolah.

2. Perlunya inovasi pada kegiatan kajian rutin dengan memiliki kurikulum dan mendatangkan pemateri dari luar cabang, supaya jama'ah lebih kaya wacana tentang islam dan kemuhammadiyahannya.

3. Meskipun kader militan lahir dari perkaderan fungsional, tetapi tidak salah ketika perkaderan Utama juga dilakukan oleh PCM Ambarawa supaya penanaman ruhiyah dan ideologi lebih intensif.

\section{DAFTAR PUSTAKA}

Anggaran Dasar dan Anggaran Rumah Tangga. 2010. Yogyakarta: Surya Sarana Grafika dan Suara Muhammadiyah

Creswell, John. 2014. Penelitian Kualitatif E Desain Riset. Yogyakarta: Pustaka Pelajar Fredian Tonny Nasdian (ed.). 2015. Sosiologi Umum.Jakarta: Yayasan Pustaka Obor 
PROFETIKA, Jurnal Studi Islam, Vol.20, No. 1, Juni 2018: 30-40

Indonesia

J Susanto (2016) http://repository.unpas.ac.id/13089/5/BAB\%20II.pdf

Kamal, Musthafa. 2009. Muhammadiyah Sebagai Gerakan Islam. Yogyakarta: Pustaka SM

Majelis Pendidikan Kader PP Muhammadiyah. 2018. Sistem Perkaderan Muhammadiyah. Yogyakarta: MPK PP Muhammadiyah

Nasution,R.D.(2018).AnalisisEfektifitasPolaRekrutmenKaderRantingmuhammadiyah Di Ponorogo. ARISTA, 6(1), 125-144. Retrieved from http://journal.umpo.ac.id/ index.php/aristo/article/view/782/601

Permata, A. N. (2015, Oktober 21). MENGENAL LEMBAGA PENGEMBANGAN CABANGDAN RANTING MUHAMMADIYAH. Retrieved from http://lpcr. muhammadiyah.or.id/:http://lpcr.muhammadiyah.or.id/muhfile/lpcr/ download/MENGENAL\%20LEMBAGA\% 20PENGEMBANGAN.pdf

Rahmawati, R. F. (2016). Kaderisasi Dakwah Melalui Lembaga Pendidikan Islam. Tadbir: Jurnal Manajemen Dakwah, 1(1), 147-166. Retrieved from http://journal. stainkudus.ac.id/index.php/tadbir/article/view/2387/1910

Redatin, P. (2006a). Kaderisasi organisasi dalam perubahan. Jurnal Wawasan, 12(1), $1-10$.

Redatin, P. (2006b). Kaderisasi organisasi dalam perubahan. Jurnal Wawasan, 12(1), 1-10. Retrieved from http://repository.usu.ac.id/bitstream/handle/123456789/16008/ was-jun2006- \%281\%29.pdf?sequence $=1 \&$ isAllowed $=y$

Shobron, S. (2010). Muhammadiyah dan strategi transformasi kader. Tajdida, 8, No. 2, 135-152. Retrieved from https://publikasiilmiah.ums.ac.id/xmlui/ handle/11617/2362

PP. Muhammadiyah. 2010. Tanfidz Keputusan Muktamar 1 Abad Muhammadiyah. Yogyakarta: Surya Sarana Grafika

Wirawan, I.B. 2012. Teori-Teori Sosial dalam Tiga Paradigma. Jakarta: Kharisma Putra Utama 